\title{
Yield Characteristics of Moringa oleifera Across Different Ecologies in Nigeria as an Index of Its Adaptation to Climate Change
}

\author{
Ndubuaku, U. M. ${ }^{1}$, Ndubuaku, T. C. N. ${ }^{2}, \&$ Ndubuaku, N. E. ${ }^{1}$ \\ ${ }^{1}$ Department of Crop Science, Faculty of Agriculture, University of Nigeria, Nsukka, Nigeria \\ ${ }^{2}$ Department of Pest Management Technology, College of Agriculture, Ishiagu, Ebonyi State, Nigeria \\ Correspondence: Ndubuaku, U. M., Department of Crop Science, Faculty of Agriculture, University of Nigeria, \\ Nsukka, Nigeria. Tel: 234-805-612-8876. E-mail: uchemay@yahoo.com
}

Received: December 13, 2013 Accepted: January 23, 2014 Online Published: January 26, 2014

doi:10.5539/sar.v3n1p95

URL: http://dx.doi.org/10.5539/sar.v3n1p95

\begin{abstract}
The pod and yield characteristics of Moringa oleifera plants grown in Ibadan (Rainforest vegetation), Nsukka (Forest-derived savannah vegetation) and Jos (arid derived savannah vegetation) were evaluated from 2007- 2009 to assess adaptability of the plant to climate change threats. The rainfall and temperature distribution in the three locations varied over the years. The Moringa oleifera plants grown at Ibadan had the greatest pod and seed yield followed by those at Nsukka and Jos in that order. The annual pod and seed production capacities of the plants differed significantly $(\mathrm{p}<0.05)$ in the different locations. The overall annual pod and seed production per location, including yield characteristics, did not differ significantly throughout the years of study. Moringa oleifera was therefore found to be a suitable crop adaptable to various environmental and climatic changes in Nigeria.
\end{abstract}

Keywords: Moringa oleifera, climate change, Ibadan, Nsukka, Jos, Nigeria

\section{Introduction}

Moringa oleifera, known as Moringa, is a tree that has been considered by the global scientific community as having the highest protein ratio of any plant. It is a readily available tool to help prevent malnutrition in children, pregnant women and nursing mothers. It is native to India but has spread from there to the tropical and sub-tropical world (Fuglie, 2000; Johnson, 2005). Moringa has been in use for many centuries in traditional alternative medicine to heal or prevent hundreds of diseases (Monzon, 1995; Ram, 1994), and because of its numerous healing and nutritional properties, it is called "Miracle Tree", "Mother's Best Friend" and "Never Die". The other common names of Moringa include "horseradish tree" and "drumstick tree". In Nigeria, the Igbos call it "Ekwe Oyibo", the Hausas call it "Zogallagandi" and the Yoruba's call it "Ewe Igbale". Moringa is drought-resistant and fast growing. A mature moringa plant grows to a height of 6-7 m (Ramachandran et al., 1980; Fuglie, 1999). It has a long, tuberous tap root that grows very deep into the soil to absorb water and mineral salts from the sub soil. This enables the plant to survive in dry seasons. Thus, moringa plants remain evergreen. It flowers at least four times a year starting from January and produces long, triangular, slender pods about 30-50 cm long (Jahn, 1996; Martin, 2000). For green leaf production, the seeds can be planted as closely as $10 \mathrm{~cm}$ apart. When the plants reach a height of one meter, they can be cut down to a height of $30 \mathrm{~cm}$. The stumps survive the harvest and will re-sprout in 50 days. With this technique, a Moringa garden can continually produce green leaves for several years with very little labour required. The all-season flushing, high flowering and pod production capacity coupled with the deep-rooted tap root and shallow lateral and tertiary roots constitute suitable adaptive features for Moringa oleifera plant against the climate change and food insecurity threats in Nigeria, tropical and subtropical regions of the world.

The study was carried out to evaluate the annual yield of Moringa oleifera plant in different ecological locations in Nigeria against variations in the climatic conditions over the years.

\section{Materials and Methods}

The pod and seed yields in Moringa oleifera plant were studied in Ibadan, Nsukka and Jos; representing different ecological locations in Nigeria i.e. Nsukka (Forest derived savannah), Ibadan (Rain forest) and Jos (Arid savannah). Nsukka lies on altitude $447.2 \mathrm{~m}$ with mean annual rainfall of 2500-3000 mm and temperature, 22- 25 ${ }^{\circ} \mathrm{C}$. The soil type is ferrasol with young sedimentary rocks. Jos and Ibadan have Eutrophic lateritic soil and sandy loam with young sedimentary rocks respectively. They are situated 1286 and $100 \mathrm{~m}$ above the sea level with 
rainfall and temperature ranges of $1422 \mathrm{~mm}$ and $22{ }^{\circ} \mathrm{C}$ (for Jos) and $1500-2000 \mathrm{~mm}$ and $27{ }^{\circ} \mathrm{C}$ (for Ibadan). The rainfall and temperature distribution in the three ecological zones were studied for three years; from 2007 to 2009. Data on pod and seed yield characteristics were collected at maturity. The moringa plants were established in the different locations one year before the study. In each location, planting was done directly on the field at $1 \mathrm{~m} \times 1 \mathrm{~m}$ and plants were randomly arranged in plots (blocks) in three different areas of a location to represent the replicates. The plots were manually weeded as the need arose in each location and there were no fertilizer and pesticide application.

\section{Results and Discussion}

The high yielding and drought resistant qualities of Moringa oleifera plant have been fully exhibited in this study with its mean annual pod yield capacity of 37.69 tonnes/ha/yr and seed yield capacity of 16.74 tonnes/ha/yr across the zones. Moringa oleifera plants grew and yielded very well in all the ecological locations considered in the study even in the arid savanna zone of Jos. There was also consistency in its pod and seed production capacities irrespective of the weather changes over the three years of study. The Moringa plants at Jos had the least number of pods over the years and the annual pod production differed significantly $(\mathrm{p}<0.05)$ in the different locations (Table 1). However, the difference in the overall yearly production of the pods, in terms of number of pods/plant, in all the locations was insignificant $(p>0.05)$. The pods of the Moringa plants at Jos also had the least lengths compared with those at Ibadan and Nsukka. The pod yield (tonnes/ha/yr) and other yield attributes of the moringa plants grown at Jos also had the lowest values. Moringa plants at Ibadan recorded the highest pod yield (in tonnes/ha/yr) in each year of study with slightly higher values of the other pod yield attributes than those at Nsukka, especially in the years 2007 and 2009. In 2008, pod number and length were higher at Nsukka than Ibadan (Table 1).

Table 1. Annual pod yield of Moringa oleifera plants at Ibadan, Nsukka and Jos in 2007, 2008 and 2009

\begin{tabular}{|c|c|c|c|c|c|c|}
\hline \multirow[b]{2}{*}{ Year } & \multirow[b]{2}{*}{ Location } & \multicolumn{4}{|c|}{ Pod Yield Characteristics } & \multirow[b]{2}{*}{$\begin{array}{c}\text { Pod Yield } \\
\text { (tonnes/ ha/ yr) }\end{array}$} \\
\hline & & $\begin{array}{l}\text { Mean number } \\
\text { of pods/ plant }\end{array}$ & $\begin{array}{l}\text { Mean pod } \\
\text { length }(\mathrm{cm})\end{array}$ & $\begin{array}{c}\text { Mean pod fresh } \\
\text { weight/ plant }(\mathrm{kg})\end{array}$ & $\begin{array}{c}\text { Mean pod dry } \\
\text { weight/ plant }(\mathrm{kg})\end{array}$ & \\
\hline & Ibadan & 405 & 45.6 & 32 & 10.5 & 50.4 \\
\hline & Nsukka & 400 & 45.5 & 30 & 9 & 43.2 \\
\hline \multirow[t]{5}{*}{2007} & Jos & 313 & 33.5 & 15.65 & 3.91 & 18.77 \\
\hline & Mean & 372.67 & 41.53 & 25.8 & 7.8 & 37.43 \\
\hline & $\mathrm{LSD}_{0.05}$ & 9.33 & 2.83 & 3.19 & 1.1 & 4.32 \\
\hline & Ibadan & 400 & 44.8 & 31.65 & 10.38 & 49.8 \\
\hline & Nsukka & 410 & 46.28 & 30.84 & 9.31 & 44.7 \\
\hline \multirow[t]{3}{*}{2008} & Jos & 325 & 34.2 & 16.86 & 3.94 & 18.92 \\
\hline & Mean & 378.33 & 41.76 & 26.45 & 7.88 & 37.81 \\
\hline & $\operatorname{LSD}_{0.05}$ & 7.72 & 2.14 & 2.28 & 1.58 & 3.46 \\
\hline \multirow[t]{5}{*}{2009} & Ibadan & 411 & 46 & 35.62 & 10.69 & 51.3 \\
\hline & Nsukka & 406 & 45.1 & 30.25 & 9.06 & 43.5 \\
\hline & Jos & 316 & 31.3 & 15.58 & 3.9 & 18.71 \\
\hline & Mean & 377.67 & 44.9 & 27.15 & 7.88 & 37.84 \\
\hline & $\mathrm{LSD}_{0.05}$ & 7.85 & 3.69 & 3.41 & 2 & 4.37 \\
\hline
\end{tabular}

Mean Annual Pod Production $=37.69$ tonnes/ha/yr.

$\mathrm{LSD}_{0.05}$ for Mean Annual Pod Production = not significant.

The values of the entire seed yield attributes and seed yield (tonnes/ha/yr) were consistently highest in the Moringa plants grown at Ibadan followed by those at Nsukka and Jos in that order (Table 2). Despite the variations in the seed yield attributes, the overall seed production did not differ significantly $(\mathrm{p}>0.05)$ from year to year; except the number of seeds/plant. 
Table 2. Annual seed yield of Moringa oleifera plants at Ibadan, Nsukka and Jos in 2007, 2008 and 2009

\begin{tabular}{|c|c|c|c|c|c|c|c|c|}
\hline \multirow[b]{2}{*}{ Year } & \multirow[b]{2}{*}{ Location } & \multicolumn{7}{|c|}{ Seed Yield Characteristics } \\
\hline & & $\begin{array}{c}\text { Number } \\
\text { of seeds/ } \\
\text { pod }\end{array}$ & $\begin{array}{c}\text { Number of } \\
\text { seeds/ } \\
\text { plant }\end{array}$ & $\begin{array}{c}\text { Mean } \\
\text { weight of } \\
\text { seeds/ pod } \\
\text { (g) }\end{array}$ & $\begin{array}{c}\text { Fresh } \\
\text { weight of } \\
\text { seeds/ plant } \\
(\mathrm{kg})\end{array}$ & $\begin{array}{c}\text { Dry } \\
\text { weight of } \\
\text { seeds/ pod } \\
\text { (g) }\end{array}$ & $\begin{array}{l}\text { Dry weight } \\
\text { of seeds/ } \\
\text { plant(kg) }\end{array}$ & $\begin{array}{c}\text { Seed Yield } \\
\text { (tonnes/ ha/ } \\
\text { yr) }\end{array}$ \\
\hline \multirow{6}{*}{2007} & Ibadan & 30 & 21,150 & 36 & 14.58 & 12.9 & 4.86 & 23.33 \\
\hline & Nsukka & 29 & 11,600 & 33.35 & 13.34 & 10.15 & 4.06 & 19.49 \\
\hline & Jos & 16 & 5,008 & 14.4 & 2.82 & 4.48 & 1.4 & 6.73 \\
\hline & Mean & 25 & 12,586 & 27.92 & 10.25 & 9.18 & 3.44 & 16.517 \\
\hline & $\mathrm{LSD}_{0.05}$ & 3 & 8705 & 3.68 & 2.73 & 2.17 & 1.43 & 3.13 \\
\hline & Ibadan & 31 & 12,400 & 35 & 15.12 & 12.81 & 4.68 & 23.72 \\
\hline \multirow{4}{*}{2008} & Nsukka & 30 & 12,300 & 33.25 & 13.66 & 10.23 & 4.05 & 19.4 \\
\hline & Jos & 18 & 5,850 & 15 & 3.05 & 5.06 & 1.8 & 6.77 \\
\hline & Mean & 26.33 & 10,180 & 27.75 & 10.61 & 9.37 & 3.51 & 16.63 \\
\hline & $\mathrm{LSD}_{0.05}$ & 2.89 & 65.83 & 3.57 & 2.75 & 2.08 & 1.31 & 3.14 \\
\hline \multirow[t]{5}{*}{2009} & Ibadan & 35 & 14,385 & 37.1 & 14.96 & 13.08 & 5.03 & 24.01 \\
\hline & Nsukka & 31 & 12,586 & 32.75 & 14.01 & 11.12 & 4.24 & 20.11 \\
\hline & Jos & 20 & 6,320 & 1480 & 4.21 & 4.66 & 1.65 & 7.12 \\
\hline & Mean & 28.67 & 11.017 & 28.22 & 11.06 & 9.62 & 3.64 & 17.08 \\
\hline & $\operatorname{LSD}_{0.05}$ & 2.94 & 69.4 & 3.66 & 2.62 & 2.23 & 1.41 & 3.16 \\
\hline
\end{tabular}

Mean Annual Seed Production $=16.74$ tonnes/ha/yr.

$\mathrm{LSD}_{0.05}$ for Mean Annual Seed Production = not significant.

The rainfall distribution from 2007 to 2009 varied in the various locations. Nsukka had two peaks of rainfall in July and October each year. Ibadan had two peaks of rainfall in July and October, 2007. In 2008 and 2009, Ibadan had its peaks of monthly rainfall in June and October. Jos had only one peak of rainfall in July each year. The total annual rainfall was highest at Ibadan followed by Nsukka and then Jos, in that order, in the three years of the study (Figures 1, 2 and 3).

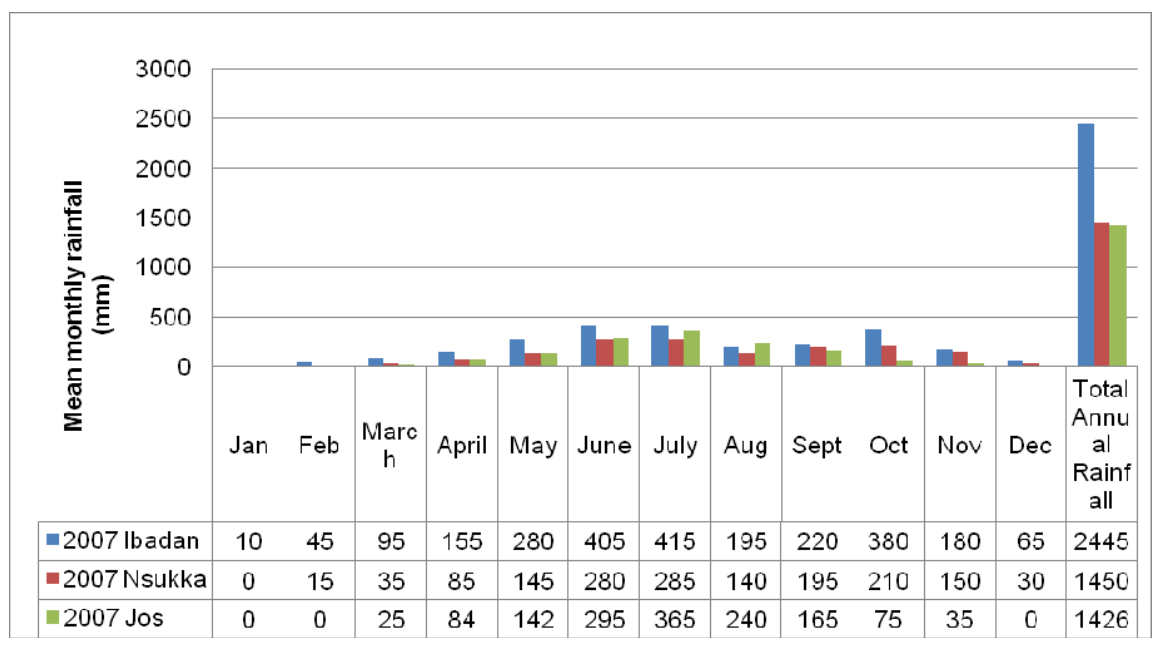

Figure 1. Mean monthly rainfall (mm) at Ibadan, Nsukka and Jos in 2007 


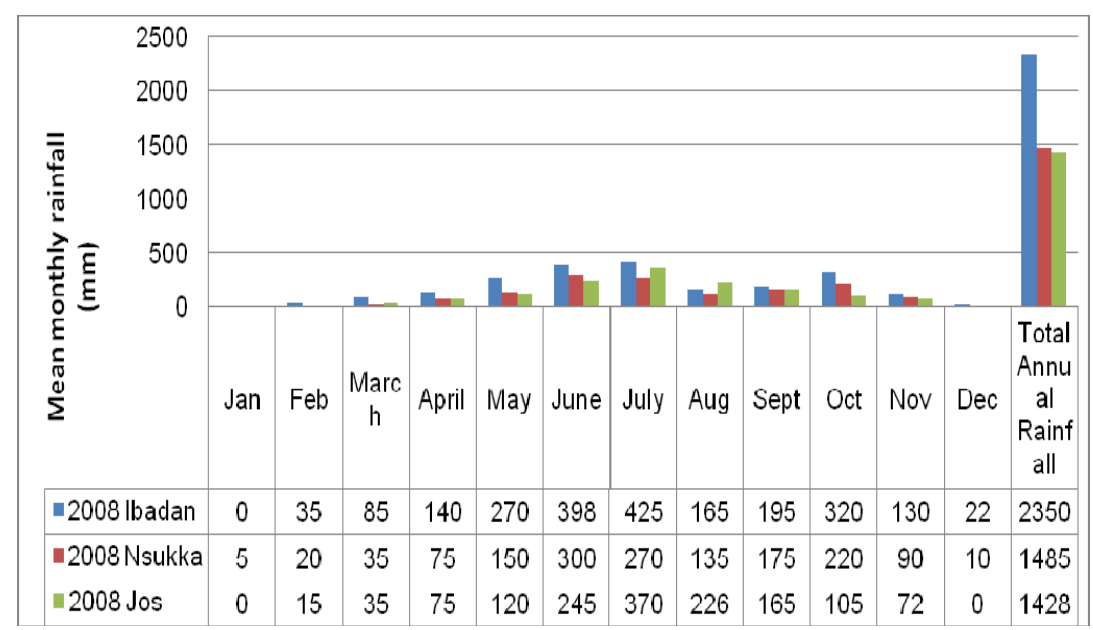

Figure 2. Mean monthly rainfall (mm) at Ibadan, Nsukka and Jos in 2008

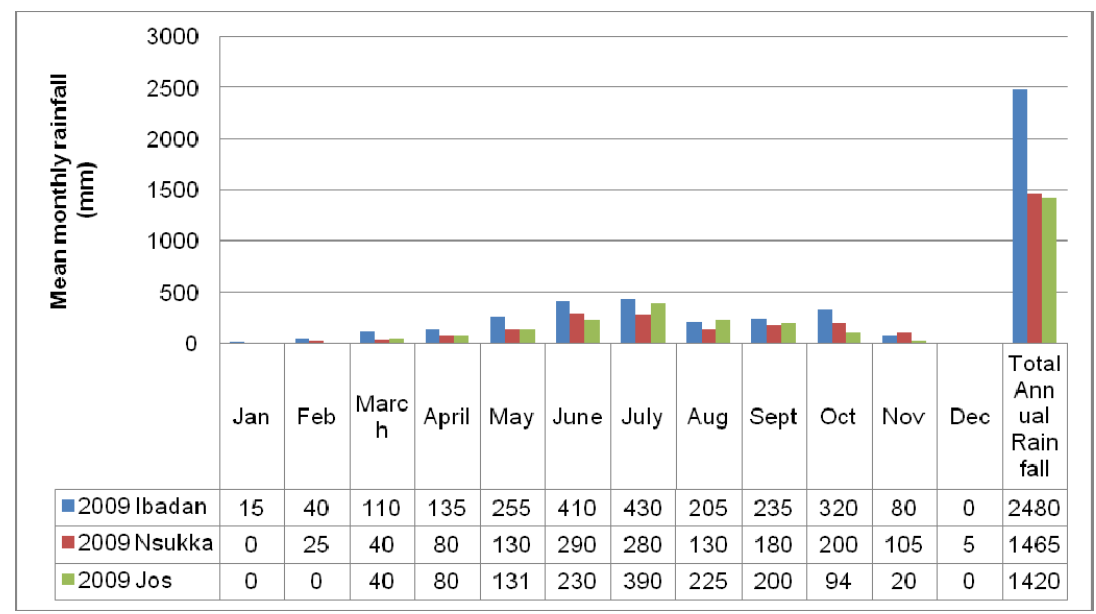

Figure 3. Mean monthly rainfall (mm) at Ibadan, Nsukka and Jos in 2009

The temperature distribution in the various locations varied also with higher monthly temperatures during the dry months of January, February, and March. In all the locations, the temperature came down during the months of regular rains in May, June, July, etc. (Figures 4, 5 and 6). The mean annual temperature was highest in Ibadan all through the three years followed by Nsukka and Jos.

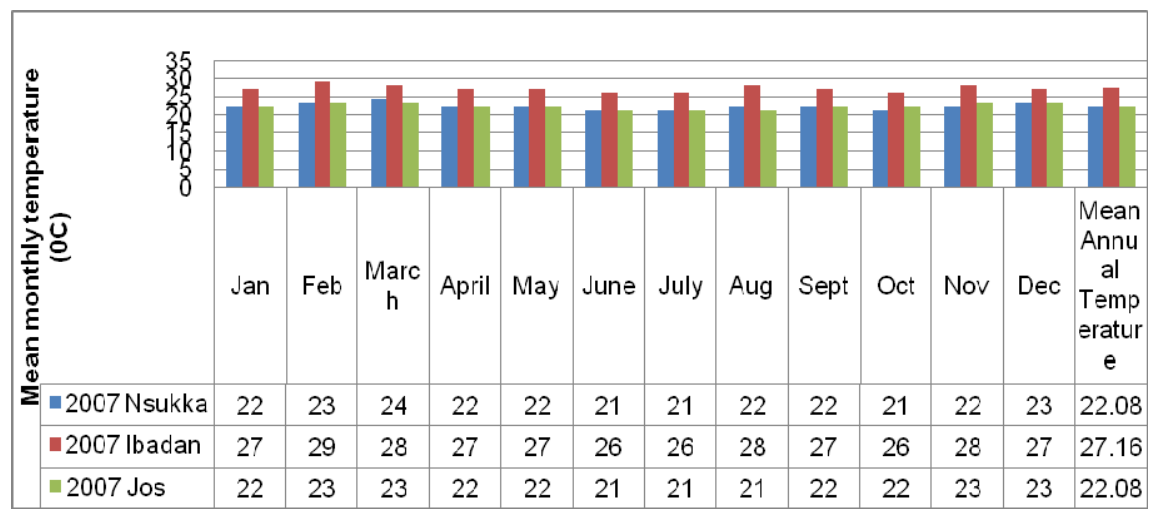

Figure 4. Mean monthly temperature $\left({ }^{\circ} \mathrm{C}\right)$ at Ibadan, Nsukka and Jos in 2007 


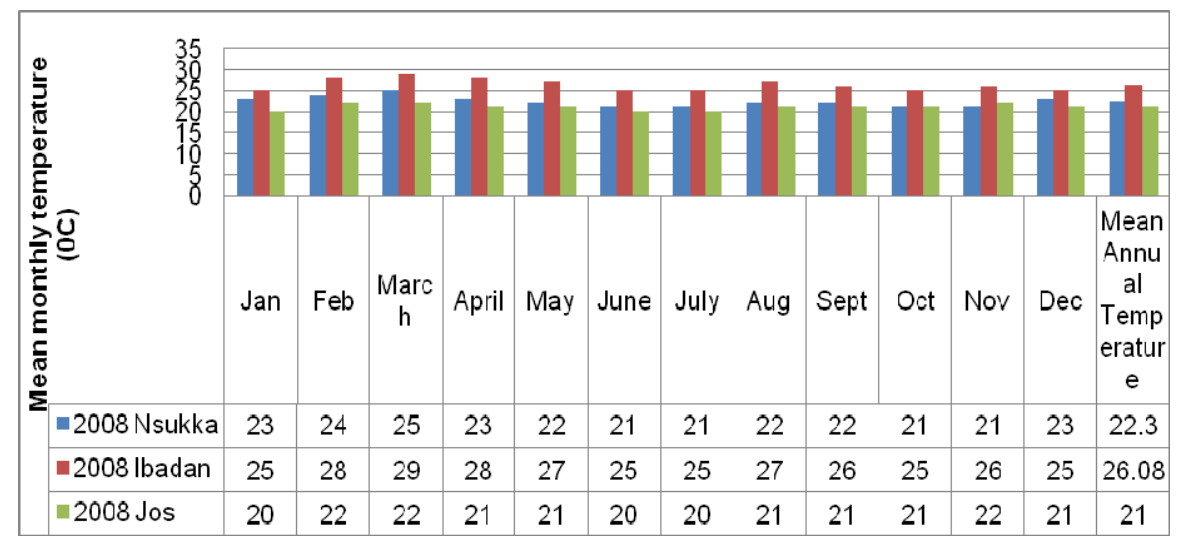

Figure 5. Mean monthly temperature $\left({ }^{\circ} \mathrm{C}\right)$ at Ibadan, Nsukka and Jos in 2008

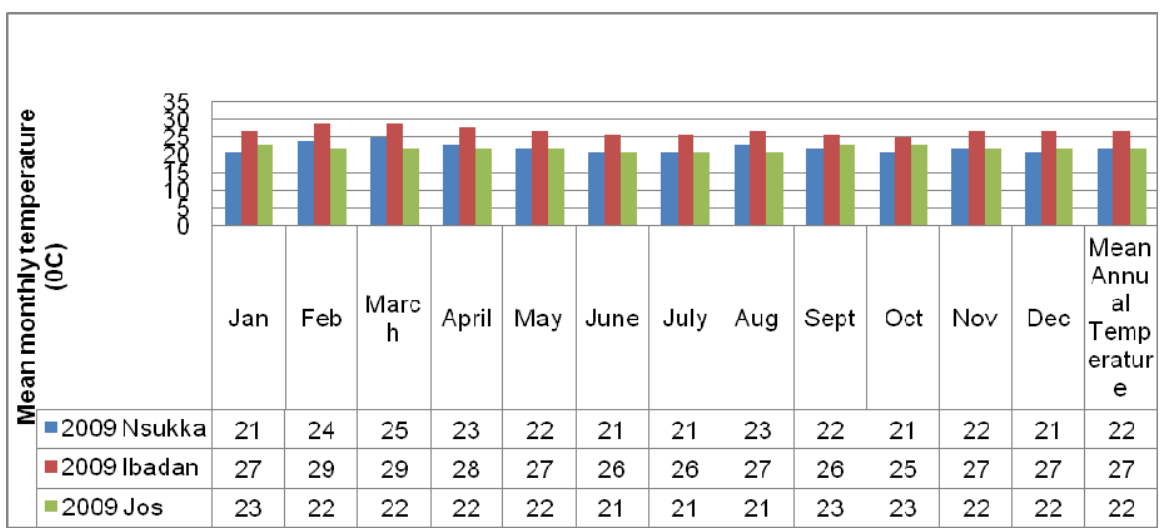

Figure 6. Mean monthly temperature $\left({ }^{\circ} \mathrm{C}\right)$ at Ibadan, Nsukka and Jos in 2009

There is clear evidence that Moringa oleifera is, no doubt, a suitable crop for climate change in Nigeria given its high level of adaptability and numerous nutritional, medicinal, agricultural, domestic and industrial values. Moringa oleifera is called a "Never Die" plant because of its adaptability to weather, soil and other environmental vagaries according to Fuglie (2000). Moringa oleifera has wide adaptability to different environments as revealed in this study. Type of vegetation was not a limiting factor to growth and well performance of moringa in the different ecologies. The heavy flushes produced by the trees even during the dry season act as good sink for carbondioxide absorption and utilization, thus reducing the level of atmospheric carbondioxide which is one of the major courses of ozone layer depletion and global warming. The high yielding quality of Moringa oleifera plant irrespective of the location, soil type, vegetation and climate conditions is a score against food insecurity in Nigeria. It is also a diver into the African Technology Policy Studies (ATPS) and the Women Innovation Challenge (WE CAN) program. Moringa is an anti-malnutrition crop. All parts of the plant, i.e. the leaves, flowers, seeds, pods are edible. The leaves, stem, bark and roots are also medicinal. Moringa oleifera is called "A Mother's Best Friend" because of its multi- nutritional and medicinal values according to Fulie $(1999,2000)$ and Johnson $(2005)$.

\section{Conclusion}

Moringa oleifera is a climate-change-adaptable crop for life sustenance against food insecurity threats. Large production of the trees is, therefore, advocated especially amongst the women. It does not only add to the home-use foodstuff but also creates job opportunities for women and their children for their capacity building. It reduces death toll due to malnutrition and diseases.

\section{References}

Fuglie, L. J. (1999). The Miracle Tree: Moringa oleifera. Natural Nutrition for the Tropics. Church World Service, Dakar. p. 68; revised in 2001 and published as The Miracle Tree: The Multiple Attributes of Moringa, p. 172.

Fuglie, L. J. (2000). New Uses of Moringa studied in Nicaragua. ECHO Development Notes \#68, June, 2000.

Jahn, S. A. A. (1996). On the introduction of a tropical multipurpose tree to China traditional and potential 
utilisation of Moringa oleifera Lamark. Senckenbergiana Biologica, 75(1-2), 243-254.

Johnson, B. C. (2005). Clinical perspectives on the health effects of Moringa oleifera: A promising adjunct for balanced nutrition and better health. KOS Health Publications.

Martin, L. P. (2000). The Moringa Tree: Revised in 2000 by Kristin Davis, pp. 1-14.

Monzon, R. B. (1995). Traditional medicine in the treatment of parasitic diseases in the Philippines. Southeast Asian Journal of Tropical Medicine and Public Health, 26(3), 421-428.

Ram, J. (1994). Moringa, a highly nutritious vegetable tree, Tropical Rural and Island/ a toll 152 Development Experimental Station (TRIADES), Technical Bulletin No. 2.

Ramachandran, C., Peter, K. V., \& Gopalakrishnan, P. K. (1980). Drumstick (Moringa oleifera): 154 A multipurpose Indian vegetable. Economic Botany, 34(3), 276-283. http://dx.doi.org/10.1007/BF02858648

\section{Copyrights}

Copyright for this article is retained by the author(s), with first publication rights granted to the journal.

This is an open-access article distributed under the terms and conditions of the Creative Commons Attribution license (http://creativecommons.org/licenses/by/3.0/). 